\title{
On Innovation of Practice Teaching for Tourism Management Based on Demands of market
}

\author{
Jianbo He \\ College of Tourism \\ Jiangxi Science \& Technology Normal University \\ Nanchang, China \\ e-mail: johnnyhay@163.com
}

\author{
Zhen Wang \\ College of Foreign Languages \\ Jiangxi Science \& Technology Normal University \\ Nanchang, China \\ e-mail: windy8299@126.com
}

\begin{abstract}
With the continuous development of tourism industry and tourism education, the significance of practice teaching on personnel cultivation and education in tourism management major is more and more prominent. Practice teaching is the important path and teaching mode for fostering the occupational abilities of tourism majors. The article analyzes the necessity and existing problems of practice teaching in present tourism education and thus puts forward some creative thoughts about the reforming and innovation in practice teaching of tourism higher education.
\end{abstract}

Keywords-tourism industry; practice teaching; tourism education; tourism major; innovation

\section{INTRODUCTION}

Practice teaching of tourism management professionals are not merely satisfied to the achievements of verifying theoretical teaching, but pay more attention to the development of students' comprehensive qualities and practical as well as innovation ability. Practice teaching of tourism management is the effective means to ensure the quality of Tourism Specialty Teaching, it can cultivate students to actively think and participate in the awareness of cooperation, help them to learn about society, and promote their ability of communication. Strengthen the practice teaching of tourism management major is an important aspect in tourism management personnel training that we can not ignore.

\section{ANALYSIS OF THE NECESSITIES OF PRACTICE TEACHING FOR TOURISM MANAGEMENT MAJOR}

\section{A. To Meet Rapid Development of Tourism industry's demand for talents}

With the speeding development of tourism in our country, the number of personnel engaged in tourism has been rapidly increasing, and tourism education also cultivates large number of tourism major talents, basically meeting the needs of tourism development. However, judging from China's current tourism development situation, there are still some structural contradictions existing between the high speed development of tourism and tourism construction discipline, between tourism personnel training and development needs. To some degree, this restricts the development of tourism industry and the promotion of the quality of tourism services. Thus, enhance the training of tourism students practical ability is the inevitable requirement of adapting to the rapid development of the tourism industry and promoting the strength and competitiveness of tourism.

\section{B. Demands of Features of Tourism Management major}

Tourism management major is a management subject with strong applicability, requiring tourism major students not only to have rich professional knowledge of basic theory and tourism management. More importantly, tourism, as a kind of service industry, has particularly high requirements for staff service and practical skills. And from the characteristics of service industry, practitioners should have certain professional service skills when providing services to the customers, thus deliver value to customers and to provide them with satisfactory service. Consequently, it requires practice teaching for tourism major students, thus enhance students' awareness for jobs and work goals in practical work.

\section{Demands for Occupational Development of Ttourism Major Students}

The training purpose of tourism management is to foster the professions in practice teaching, and such a development is also to the service of tourism industry. This developmental direction sticks out the tourism practical teaching features. It can also help students to form the right cognition of jobs, develop eligible profession quality as well as recognize the career direction, which provides solid foundation for later development. 


\section{PROBlems EXISTING IN THE TOURISM MANAGEMENT PRACTICE TEACHING}

\section{A. The teachers Abilities of Practice Teaching are relatively weak}

Seeing from the development of our education in tourism, the education in tourism has developed rapidly though, lots of majors of tourism in tourism college have still been restrained because of teaching qualification and condition, tourism is still lacking of the practical operation and managerial experience, leading to the situation that more theory in class, less practice and the conflict between theory and practice and the decline of student's ability of practicing, even causes that the development of theory can't keep the pace with tourism badly, though college teacher is qualified with the theory of tourism. Furthermore, the shortage of capital and limited equipment cannot satisfy the requirements of practical teaching of tourism management.

\section{B. The Construction of Practice Teaching Become a mere formality}

The template is used to format your paper and style the text. All margins, column widths, line spaces, and text fonts are prescribed; please do not alter them. You may note peculiarities. For example, the head margin in this template measures proportionately more than is customary. This measurement and others are deliberate, using specifications that anticipate your paper as one part of the entire proceedings, and not as an independent document. Please do not revise any of the current designations.

\section{The Mismatch between Design of Practice Teaching and Market Demands}

The practice teaching of tourism management major is not only to guarantee of realizing the talents training target, but the combination of work practice and talents training. Such a pattern can be more targeted and rational. But from the point of the design of practice teaching of tourism management major, schools are always starting from their own understandings, over stressed the teaching demands in practical teaching while ignoring the needs for talents in society and enterprises. Thus, this can give rise to the mismatch between the design of tourism management major practical teaching and job requirements that Is not conducive to the implementation of practice teaching, in the mean time, the students will lack of the sense of identifying of practice teaching.

The problems above directly influence the effectiveness of practice teaching in tourism management teaching, we can neither complete the goals in teaching schedule, nor cultivate the basic character of getting directly to the job after graduating. Thus, how to deal with the problem existing in the practice teaching of tourism management professional teaching in some universities, making rational plans of the practice teaching, formulating scientific management strategies and giving seriously implement comes to the priority in tourism in practice teaching.

\section{The Shortage of Practical Skills and Managrial Skills For Students}

As the teaching aim of colleges, the selection and appointment of human resources of tourism enterprises will focus on the practical needs of enterprises. Besides, the practice teaching of tourism major is a relatively short-term teaching activity. For these reasons, the students will be appointed in some fixed positions. Most of them will take on some simple and repetitive jobs such as tour guides, OPs, room attendants, waiters/waitress, bellmen, etc. During the whole practice teaching period, they will be fixed in these positions, which will have some negative effects on the students. As a result, the students can't realize the significance of practice teaching fully and the effect of practice teaching is also be reduced greatly.

\section{Thoughts of Strengthening PRACTICE TEACHING OF TOURISM MAJOR}

\section{A. Taking cultivating Professional Talents of Tourism major as Core}

No matter in theoretical teaching or practical teaching, the fundamental purpose of education is to train qualified personnel. Consequently, in order to strengthen the practice teaching in tourism management, we must make educating as the fundamental goal of teaching. Based on the ability of students, bring the constitution and implementation between practical teaching plan and syllabus, the development of teaching staff and equipment as well as practice base together to develop students ability of practice and innovation, guarantee the successful process of practice training.

\section{B. Aiming at Occupational Development of Tourism Majors}

Cultivating the tourism professional teaching talent is to adapt the development of tourism industry, thus, during the practice teaching, we must develop in the direction of meeting the needs of tourism, combine the fundamental goal of occupation development with student education. Through the practice teaching, we must let students realize real tourism industry such as the characteristics of tourism enterprises, namely, travel agency, tourism Hotel, tourist attractions in specific practice training. Combine the occupation development planning of tourism with industry's demand for talents and give priority to the cultivation of practical ability, problem handling ability, management ability and innovation ability.

\section{Based on Mutual benefits of Cooperation between Colleges and Enterprises}

Tourism management profession practice teaching must rely on the common efforts of both sides between colleges and enterprises :as the tourism management colleges, they generally lack the basic conditions of tourism management profession practice teaching and the realistic background of enterprises; as tourism enterprises, they need new ideas and 
talents to promote the healthy development of the enterprise, and tourism management profession practice teaching link is a combination of good link, tourism colleges can obtain rich experience in tourism management practice and timely grasp the status and the trend of development through cooperation; what's more, tourism can obtain the excellent intellectual resources and human resources support to help solve the problems of the development of tourism enterprises, rich reserving of talents can also be used for its own development.

\section{Guranteeded by Good Operational Mechanism}

To achieve the goal of practice teaching in tourism management major must rely on the good operational mechanism to ensure. We should include the real practice teaching in tourism management major teaching system to guarantee the systematicness and stability by conducting the practice teaching in tourism management profession. Conducting the practice teaching evaluation mechanism is to help the students set up their own career development goals at the beginning of practice teaching. In the process of practice teaching, it can ensure the students' practical jobs and career development goals are consistent and to evaluate the students' completion. Conducting the incentive mechanism of practice teaching and giving proper rewards to the students with excellent performance is to encourage the students' self-consciousness and initiative in the practice of practical teaching activities so that we can conduct a comprehensive monitoring and ensure the operation and effect of practice teaching.

\section{THE CREATIVE TACTICS FOR STRENGTHENING PRACTICE TEACHING FOR TOURISM MAJOR}

\section{A. To Strengthen the Construction of Teaching Faculties}

First of all, in order to construct double type teaching staff which suit the development of tourism theory and industry, we should not only possess the strong knowledge of fundamental tourism theory and teaching -research level, but also have strong ability of professional practice and abundant practical experience so that we can give the students the reasonable planning and guidance of practice teaching of the practice teaching to help the students set up the correct understanding. Secondly, teachers are required to participate in a planned way in the credential exercises provided by tourism enterprises to improve the teachers' practical abilities: through studying advanced management experience and service procedures and service standards at the star hotel, travel agency and scenic spot to improve teachers' level and practical ability of combining the theory and practice, in a timely manner to enrich , update the practice teaching content of teachers to adapt to the needs of the development of tourism industry .In addition, while strengthening the training of the tourism college teachers, tourism enterprise personnel can be employed for the school part-time job to bring the latest experience and methods of tourism enterprise management into the classroom. Holding the direct exchanges and communication between students and enterprises can help students understand the characteristics of tourism enterprises and working conditions to reduce the obstacles in the tourism practice teaching and strengthen the connection between the tourism and promote teachers to have more opportunities to learn and research in the practice teaching.

\section{B. To Condense the Major Features and Construct Brand Major}

Tourism management, as a practical applied science in particular, includes hotel management, travel agencies, tourism planning, management and administration of scenic spot, MICE tourism and other professional direction. With the rapid development of tourism education in our country, the competition in tourism industry is intense, not only reflected in the competition in tourism industry, but also reflected in the competition in tourism education. To deal with the competition of tourism development, it requires tourism colleges meet the needs of tourism industry of talent, targeting to open and develop new professional direction and to make corresponding adjustment among the faculty, discipline construction and teaching pattern. It is necessary to run a school especially to form their own differences and create professional brand so as to form their own competitive advantages.

\section{To Strengthen the Depth of College-enterprise Cooperation}

Tourism cooperation between colleges and enterprises is to use two different kinds of environments, namely, tourism colleges and tourism enterprises and resources superiority in a way of school education and enterprise practice to maximally meet the requirements of enterprises to the quality of employees and rapidly improve the students' ability to adapt so that we can shorten the development period of talent training and make the school training goal and the enterprise talent demand tight butt. In particular, it can be done by the following pattern:

\section{1) College-enterprise joint personnel training pattern:}

Tourism college-enterprise united talent cultivation is mainly tourism colleges are responsible for selecting the students worthy cultivation according to the tourism enterprises' demand for talents and the cooperation by both sides on the talent training scheme, course settings and teaching management. The colleges provide teaching sites and training for students and enterprises provide corresponding internalship facitilities and jobs for students. This is a talent training pattern that students are cultivated in a way based on the jobs that tourism enterprises need and go to the enterprises directly after graduation..This pattern can not only reduce the blindness on the students training in tourism colleges, but also reduce the training cost of tourism enterprises. In addition to, It can provide enterprises with long-term human resources guarantee. to ensure the longevity and stability of tourism cooperation between colleges and enterprises and solve the employment of 
students as well, truly realizing the effective docking between the school education and enterprise employment.

\section{2) Direct employment practice pattern :}

Tourism colleges can directly provide the resources of students for the tourism enterprise recruitment and make full use of the leading function in the tourism enterprises as alumni to influence the graduate students from tourism college through the long-term cooperation between college and enterprises. Tourism enterprises can not only help enterprises to attract talent, but also at the same time reduce the turnover rate on the tourism enterprise employee by way of providing the employment practice positions for students.

\section{3) Cooperation of Practice Teaching Base pattern:}

For this pattern, tourism colleges will sign a long-tern cooperation contract about practice teaching base with enterprises. The colleges will arrange a certain number of students to involve in management and operation of enterprises. Meanwhile, the enterprises will provide some suitable positions to tourism majors to practise. Compared with college-enterprise joint personnel training pattern, this pattern is more flexible which can set up different positions according to the damands of enterprises and the features of students. Besides, under this pattern, tourism colleges and enterprises can carry out teaching plan well in the period and damands of practice teaching.

\section{CONCLUSION}

In short, the healthy development of tourism industry needs talent .However, tourism management profession talent training not only needs the education of tourism theory ,but also in better need of the practice of tourism training .Strengthening the tourism management professional practice teaching is an effective approach to achieve the goal of talent cultivation. Tourism colleges, as the main body of education, should be more proactive in developing the long-term and stable relationship organized by the tourism enterprises in the fierce competition of tourism industry and give full play to all various aspects of resources inside and outside campus to build their own professional brand so as to provide better service for the practice training of tourism management. It can truly cultivate the talent for tourism management profession who can adapt to the development of tourism and have the theory quality and practical ability to meet the needs of the tourism development for talent.

\section{ACKNOWLEDGMENT}

This work was financially supported by the 12th Fiveyear Plan of educational science of Jiangxi Province (13YB154).

\section{REFERENCES}

[1] Raybould, Mike and Wilkins, Hugh. Overqualified and underexperieneed : Turnning graduates into hospitality managers. International Journal of Contemporary Hospitality Management, 2005, 17(3):203-216.
[2] Donn E. Brolin, Robert J. Loyd. Career Development and Transition Services.Upper Saddle River, New Jersey, 2004.

[3] Getz, Donald. Students' Work Experiences, Perceptions And Attitudes Towards Careers In Hospitality And Tourism: A Longitudinal Case Study In Spay Valley, Scotland. Internal Journal of Hospitality Management, 1994, 13(1):25.

[4] Douglas J. Kennett, James P. Kennett, Jon M. Erlandson and Kevin G. Cannariato. The international Journal of Tourism Research, 2002 (4) : 103-117.

[5] Dana V. Tesone. Development of a sustainable tourism hospitality human resources management module: a template for teaching sustainability across the curriculum. Hospitalit Management, 2004(23):207-237.

[6] Ross, Glenn F. Tourism management as a career path:vocational perceptions of Australian school leavers.Tourism Management, 1992, 13(2):242.

[7] Jenkins, A.k.Making a career of it? Hospitality students' future perspectives: An Anglo-Dutch study. International Journal of Contemporary Hospitality Management. 2001, 13(1):13-20.

[8] Sinead O'Leary and Jim Deegan. Career progression of Irish tourism and hospitality management graduates. International Journal of Contemporary Hospitality Management, 2005, 17(5):421-432.

[9] Lennon, J.John. Industrial"Needs"And Education Provision:The Case Of Hotel And Catering Management. International Journal of Hospitality Management, 1989, 8(2):111.

[10] Harvard Committee: General Education in a Free Society. Cambridge Mass: Harvard University Press, 1945.

[11] Hutchins, R.M. The Learning Society. New York: The American Library,1968.

[12] Brain King, Bob McKercher, Robert Waryszak. A Comparative Study ofHospitality and Tourism Graduates in Australia and Hong Kong, International Journal of Tourism Research, 2003(8):409-420. 